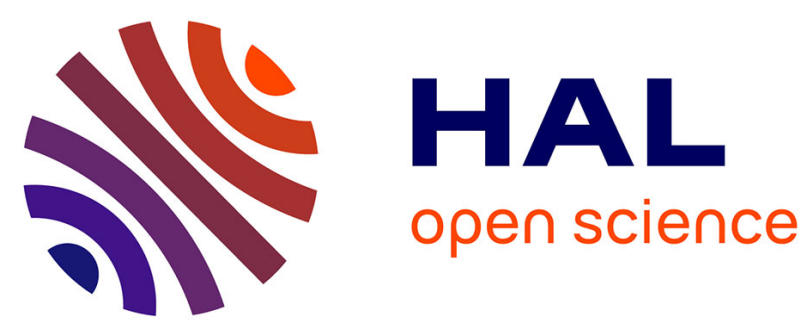

\title{
Bycatch of the European purse seine tuna fishery in the Atlantic Ocean for the 2003-2007 period
}

Monin Amandé, Javier Ariz, Emmanuel Chassot, Alicia Delgado de Molina, Daniel Gaertner, Hilario Murua, Renaud Pianet, Jon Ruiz, Pierre Chavance

\section{To cite this version:}

Monin Amandé, Javier Ariz, Emmanuel Chassot, Alicia Delgado de Molina, Daniel Gaertner, et al.. Bycatch of the European purse seine tuna fishery in the Atlantic Ocean for the 2003-2007 period. Aquatic Living Resources, 2010, 23 (4), pp.353-362. 10.1051/alr/2011003 . ird-00585907

\section{HAL Id: ird-00585907 https://hal.ird.fr/ird-00585907}

Submitted on 17 Apr 2011

HAL is a multi-disciplinary open access archive for the deposit and dissemination of scientific research documents, whether they are published or not. The documents may come from teaching and research institutions in France or abroad, or from public or private research centers.
L'archive ouverte pluridisciplinaire HAL, est destinée au dépôt et à la diffusion de documents scientifiques de niveau recherche, publiés ou non, émanant des établissements d'enseignement et de recherche français ou étrangers, des laboratoires publics ou privés. 


\title{
Bycatch of the European purse seine tuna fishery in the Atlantic Ocean for the 2003-2007 period
}

\author{
Monin Justin Amandè ${ }^{1}$, Javier Ariz ${ }^{2}$, Emmanuel Chassot ${ }^{3}$, Alicia Delgado de Molina ${ }^{2}$, Daniel Gaertner ${ }^{3}$, \\ Hilario Murua ${ }^{4}$, Renaud Pianet ${ }^{3}$, Jon Ruiz ${ }^{4}$ and Pierre Chavance ${ }^{3, a}$ \\ ${ }^{1}$ Université de Montpellier 2, Place Eugène Bataillon, 34090 Montpellier, France \\ 2 Instituto Español de Oceanografía, Apdo. Correos 1373, 38080 S/C Tenerife, Canary Island, Spain \\ 3 Institut de Recherche pour le Développement, CRHMT - UMR 212, Avenue Jean Monnet, BP 171, 34200 Sète Cedex, France \\ 4 AZTI Tecnalia, Herrera Kaia, Portualde z/g, 20110 Pasaia (Gipuzkoa), Spain
}

Received 9 February 2010, Accepted 20 October 2010

\begin{abstract}
Bycatch of several groups of species and their characteristics are presented for the period 2003 to 2007 for the European purse seine tuna fishery operating in the Atlantic Ocean. Data were collected through French and Spanish observer programmes and represented a total of 27 trips corresponding to $2.9 \%$ coverage. Bycatch is defined as nontargeted species and small or damaged target species. Bycatch species composition, main species length, sex ratio and the fate of the most common species are presented first. Stratified ratios relative to landings of major commercial tunas were then used to estimate the total bycatch; these ratios were considered the most appropriate variable for extrapolation. Stratification was based on the fishing mode (free school vs. floating object), season (quarters) and spatial areas. The annual average bycatch was estimated at about $6400 \mathrm{t}$, corresponding to a mean annual value of $80.8 \mathrm{t}$ per $1000 \mathrm{t}$ of tuna landed or $7.5 \%$ of the total catch. Tunas represent $83 \%(67.2 \mathrm{t} / 1000 \mathrm{t})$ of the total bycatch, followed by other bony fishes $(10 \%, 7.8 \mathrm{t} / 1000 \mathrm{t})$, billfishes $(5 \%, 4.0 \mathrm{t} / 1000 \mathrm{t})$, sharks $(1 \%, 0.9 \mathrm{t} / 1000 \mathrm{t})$ and rays $(1 \%, 0.9 \mathrm{t} / 1000 \mathrm{t})$. Based on estimates of the annual bycatch, $16 \%$ was kept on board and sold in local markets.
\end{abstract}

Key words: Bycatch / Discards / Tuna fisheries / Purse seining / Atlantic Ocean

Résumé - Les quantités de captures accessoires de plusieurs groupes d'espèces ainsi que leurs caractéristiques sont présentées pour la pêcherie thonière européenne à la seine opérant dans l'océan Atlantique pour la période 2003-2007. Les données ont été collectées lors de programmes d'observateurs embarqués français et espagnols représentant un total de 27 marées soit un taux de couverture de 2,9\% des marées totales. Les captures accessoires sont définies ici comme les espèces non ciblées ainsi que les individus petits ou abîmés des espèces-cibles. La composition spécifique des captures accessoires, la structure de taille des principales espèces, le sex-ratio et le devenir des espèces les plus communes sont présentés. La méthode des ratios par rapport aux débarquements d'espèces commerciales est ensuite utilisée pour estimer la quantité totale de capture accessoire. Ces ratios ont été considérés comme la variable la plus appropriée pour l'extrapolation. Une stratification a été utilisée, basée sur le mode de pêche (pêche sur banc libre versus pêche sur objet flottant), le trimestre et les zones spatiales. La quantité de capture accessoire annuelle moyenne est estimée à $6400 \mathrm{t}$, correspondant à une valeur annuelle moyenne de $80,8 \mathrm{t}$ par $1000 \mathrm{t}$ de thons commercialisés ou 7,5\% de la capture totale. Les thons représentent $83 \%(67,2 \mathrm{t} / 1000 \mathrm{t})$ du total suivis par les autres poissons osseux $(10 \%$; 7,8 t/1000 t), les poissons porte-épées $(5 \% ; 4,0 \mathrm{t} / 1000 \mathrm{t})$, les requins $(1 \% ; 0,9 \mathrm{t} / 1000 \mathrm{t})$ et les raies $(1 \% ; 0,9 \mathrm{t} / 1000 \mathrm{t})$. On estime que $16 \%$ de ces captures accessoires est conservé à bord et vendu sur le marché local.

\section{Introduction}

In recent years, the annual catch of major tropical tuna species in the Atlantic Ocean, i.e. yellowfin (Thunnus albacares), bigeye (Thunnus obesus), and skipjack (Katsuwonus pelamis), has represented an average of $350000 \mathrm{t}$, corresponding to about $9 \%$ of the overall production in tuna fisheries.

${ }^{a}$ Corresponding author: Pierre.Chavance@ird.fr
Tropical tuna species are mostly caught by industrial longline and purse seine fisheries, which currently represent about $20 \%$ and $80 \%$, respectively, of the total catch of the Atlantic Ocean (Maguire et al. 2006). In the 2000s, the European purse seine fishery operating in the eastern Atlantic Ocean consisted of a combination of 30 vessels under the flags of France and Spain (Pianet et al. 2009). Two major fishing modes are employed by the tuna purse seine fishery; sets are either made on tuna 
schools associated with floating objects (that can be artificial or natural) or on free schools.

Although tuna purse seine fisheries have been shown to be selective, leading to lower levels of bycatch (see below for definition for this term) than other fisheries (Alverson et al. 1994; Kelleher 2005), several species can be incidentally caught and, in some cases, discarded at sea. These include vulnerable and sensitive species (i.e. displaying low fecundity or slow growth rate), and charismatic species, such as turtles, mammals, and sharks (Stretta et al. 1997; Romanov 2002, 2008; LennertCody et al. 2001; Minami et al. 2007). Bycatch and associated discarding are difficult to estimate on the basis of logbook information, as they are generally poorly or not reported by fishing masters. In addition, bycatch sizes vary according to several interrelated technical, ecological, and economic factors (Pascoe 1997; Hall et al. 2000; Rochet and Trenkel 2005), making bycatch estimates and predictions difficult (Kelleher 2005). The bycatch issue is, however, of increasing concern, as this practice is thought to be responsible for economic loss, juvenile mortality and ecological effects on key species, which are relevant to the overall ecosystem structure and functioning (Garcia et al. 2003). In addition, juvenile tuna catches that are discarded or sold on local fish markets are generally absent from official statistics and, therefore, are not included in the available statistics used as inputs for stock assessment models.

Several datasets on bycatch have been collected in the past for eastern Atlantic Ocean tuna purse seine fisheries during specific projects (Santana et al. 1998; Delgado de Molina et al. 2000; Gaertner et al. 2002; Goujon 2004; Sarralde et al. 2004). However, apart from a study on billfish (Gaertner et al. 2002), an estimation of the amounts of bycatch for the entire European purse seine fishery has yet to be carried out. Such estimates are crucial for determining the extent of bycatch and discarding practices in tuna purse seine fisheries, in order to assess the effects of fishing on the ecosystem (Garcia et al. 2003). Since 2001, the European Union has established a mandatory sampling programme for the collection of data in the fisheries sector under the EU Data Collection Regulation (DCR) directive in support of its Common Fishery Policy. A major objective of the sampling programme is to estimate the amount of bycatch and discards in European fisheries. The Institut de Recherche pour le Développement (IRD), Instituto Español de Oceanografía (IEO), and AZTI Tecnalia are the French and Spanish research institutes in charge of a common framework for collecting and analyzing bycatch and discards via scientific observer programmes conducted on the tropical EU tuna purse seine fisheries that operate in the Atlantic and Indian Oceans. As recommended by the International Commission for the Conservation of Atlantic Tunas (ICCAT) and the Indian Ocean Tuna Commission (IOTC), a minimum observer coverage of $5 \%$ of the number of trips was requested. Previous studies on various groups of species of bycatch show that $10 \%$ coverage provides bycatch estimates, based on groups of species, which are accurate to between 10 and $40 \%$ (LennertCody 2001; Sanchez et al. 2007).

Data collected through the French and Spanish observer programme during 2003-2007 in the Atlantic Ocean led to the various objectives outlined in this study: (i) to describe the species and size composition and the sex of the bycatch; and (ii) to estimate the levels of bycatch and the relative percentages of discarded/landed species. The results were compared with estimates derived from observer programmes conducted before 2003 in the Atlantic Ocean and from current levels of bycatch in the western Indian Ocean.

\section{Material and methods}

\subsection{Terminology}

Different terms are used in the literature for the various components of accidental and/or unwanted catch and this may result in confusion and sometimes misunderstanding (Davies et al. 2009). Here, the following terms were adapted from FAO (1999) and Kelleher (2005):

- Total Catch: the overall biomass that is encircled and retained by the net once closed;

- Production: targeted major tuna species, such as yellowfin (Thunnus albacares), skipjack (Katsuwonus pelamis) and bigeye (Thunnus obesus), which are landed and marketed through canneries;

- Bycatch: all non-targeted species plus small or damaged target tuna species that are not marketed through canneries. The bycatch may be divided into two components: a) by-products that are kept for a particular use, i.e. to be consumed on board or sold later on the local African market; and b) discards that are rejected at sea, dead or alive.

Therefore: Total Catch $=$ Production + Bycatch and Bycatch $=$ By-products + Discards.

- "Faux poisson" (false fish) is a peculiar term for an important by-product of the purse seine fishery in West Africa and particularly in Abidjan, Ivory Coast. It is made up of a mix of damaged or undersized target tunas, minor tuna species, and associated species, like billfish, sharks, and various bony fish, that are sold on the local market (Romagny et al. 2000).

The acronym "FAD" standing for fish aggregating device, will be used here to describe any type of floating object used for fishing tuna. These include natural objects (e.g. logs, palm branches) and anthropogenic floating objects, such as manmade bamboo rafts equipped with radio-range beacons, satellite transmitters or scanning sonars. All floating objects used in the European purse seine tuna fishery are drifting devices. Fishing sets made on whales were classified as free school sets (FSC), whereas sets made on whale sharks (Rhincodon typus) were classified as FAD sets (Pallarés and Petit 1998; Gaertner et al. 2002). Natural and artificial floating objects were assumed to have similar qualitative and quantitative effects on bycatch, based on previous studies in the Eastern Pacific Ocean (Hall et al. 1999) and the absence of specific information in the regions concerned. Although differences in spatial distribution and the netting configuration may affect this assumption, the data set was not considered large enough to assess this point. 
Table 1. Observed versus total number of trips and percentage of coverage.

\begin{tabular}{cccc}
\hline Year & Observed trips & Total trips & Coverage $(\%)$ \\
\hline 2003 & 4 & 267 & 1.50 \\
2004 & 4 & 220 & 1.82 \\
2005 & 6 & 163 & 3.68 \\
2006 & 5 & 141 & 3.55 \\
2007 & 8 & 129 & 6.20 \\
\hline $2003-2007$ & 27 & 920 & 2.93 \\
\hline
\end{tabular}

\subsection{Data}

The DCR Spanish and French observer programmes were started in 2003 and 2005, respectively. They only cover French and Spanish fishing boats. Data were collected by observers over the course of 27 trips, corresponding to 598 sets in the Atlantic Ocean (latitude between $10^{\circ} \mathrm{S}$ and $15^{\circ} \mathrm{N}$ and longitude from $35^{\circ} \mathrm{W}$ to the African coast) over the 2003-2007 period. The overall coverage rate reached $2.9 \%$ of the total number of trips and increased from 1.5\% in 2003 to $6.5 \%$ in 2007 (Table 1). The fishing set was considered as the sampling unit and was categorized into log-school (FAD) and free school (FSC) sets, based on direct information reported by observers. The sample included observations made on 301 free school sets and 297 log-school sets, and corresponded to an observed tuna production of $9967 \mathrm{t}$, i.e. $4283 \mathrm{t}$ and $5684 \mathrm{t}$ from FSC and FAD sets, respectively.

Observers reported numbers of individuals or estimated weights by species, if the numbers were too high. If only numbers or weights were available, species-specific conversions were made based on information relating to the mean individual weight available in data. The sex was recorded for sharks, rays, turtles, and marine mammals. Species composition was derived from observations on all sets that were pooled together between 2003 and 2007. Species-specific length and sex frequencies were computed by summing up the size and sex frequencies weighted by the total species number in each set.

\subsection{Extrapolation method}

The ratio estimator method (Stratoudakis et al. 1999; Ye et al. 2000; Borges et al. 2005) was used here to determine the overall bycatch level. Production and number of operations were the two main candidate variables available at the fishery level for calculating the ratio estimator. Tuna production was preferred for two reasons. First, the total number of sets from the fishery in logbooks is generally underestimated, as fishing masters tend to ignore fishing operations without capture. Second, the production ratio is an interesting variable, as it is similar across fisheries that use different types of technology. Data were stratified by fishing mode (FSC or FAD), season (quarter) and areas $\left(\mathrm{ET}\right.$ areas $\left.{ }^{1}\right)$. Let,

- $H$ be the total number of strata in the fishery $(h=1,2, \ldots$, H)

\footnotetext{
1 See Pallarés and Hallier (1997) and Pianet et al. (2000) for more information on ET areas.
}

- $Y$ and $y$, the production from logbook and observer data, respectively

- $X$ and $x$, the bycatch from logbook and observer data, respectively.

The production values were known for the whole fishery, i.e. the logbook data. However, bycatch values were recorded along with associated production values in the observer data section. Assuming a linear relationship between bycatch and production in each stratum, the ratio in a given stratum, $R_{\mathrm{h}}$, is calculated by dividing the bycatch by its associated tuna production (Thompson 2002).

$$
R_{h}=\frac{\overline{x_{h}}}{\overline{y_{h}}}
$$

The estimate for the total bycatch population is given by

$$
X=\sum_{h=1}^{H} X_{h}=\sum_{h=1}^{H} R_{h} . Y_{h} .
$$

Where $Y_{\mathrm{h}}$ are the production values in the $h^{\text {th }}$ stratum. Confidence interval of the bycatch per species group was calculated by non parametric bootstrap procedure via the boot package of $R$ statistical computing software (Canty and Ripley 2010).

\section{Results}

\subsection{Tuna}

Tuna are the main component of the bycatch. The bycatch consisted of $828 \mathrm{t}$ of tuna, corresponding to about 751000 individuals, for the period 2003-2007 (Table 2). The most dominant species encountered was skipjack (Katsuwonus pelamis), followed by little tunny (Euthynnus alletteratus) and bullet tuna (Auxis rochei). Skipjacks were almost exclusively caught under FAD-associated sets and their bycatch length distribution indicated a median fork length of $37 \mathrm{~cm}$, with $2.5 \%$ and $97.5 \%$ quantiles equal to $32 \mathrm{~cm}$ and $48 \mathrm{~cm}$, respectively, corresponding to fish $<1.5 \mathrm{~kg}$ (Fig. 1). Little tunny were also caught more frequently under FAD-set operations than under free school sets, and their bycatch median fork length was $45 \mathrm{~cm}$, with $2.5 \%$ and $97.5 \%$ quantiles at $38 \mathrm{~cm}$ and $53 \mathrm{~cm}$, respectively (Fig. 1).

\subsection{Billfish}

A total of 581 billfish $(27 \mathrm{t})$ were observed over the time period considered. Six species of billfish were identified by observers on board: Atlantic sailfish (Istiophorus albicans), blue marlin (Makaira nigricans), white marlin (Tetrapturus albidus), swordfish (Xiphias gladius), black marlin (Makaira indica) and the shortbill spearfish (Tetrapturus angustirostris). Species composition was dominated by Atlantic sailfish, followed by blue marlin (Table 2). Atlantic sailfish were more frequently associated with free schools, whereas the other billfish species occurred more frequently under FAD-associated sets. Low jaw-fork length of Atlantic sailfish varied from 132 
Table 2. Bycatch composition in number and weight by fishing mode (FSC and FAD) for the whole period (2003-2007). (*) Marine mammals and whale sharks are not included, see text for more information.

\begin{tabular}{|c|c|c|c|c|c|c|c|c|}
\hline \multirow[b]{2}{*}{ Species group $(*)$} & \multirow[b]{2}{*}{ Vernacular name } & \multirow[b]{2}{*}{ Species } & \multicolumn{2}{|c|}{ FSC } & \multicolumn{2}{|c|}{ FAD } & \multicolumn{2}{|c|}{ Total } \\
\hline & & & Number $(\%)$ & $\begin{array}{c}\text { Weight } \\
\text { in tons }(\%)\end{array}$ & Number $(\%)$ & $\begin{array}{c}\text { Weight } \\
\text { in tons }(\%)\end{array}$ & Number (\%) & $\begin{array}{c}\text { Weight } \\
\text { in tons }(\%)\end{array}$ \\
\hline \multirow[t]{8}{*}{ Tuna } & Skipjack tuna & Katsuwonus pelamis & $102(0.1)$ & $0.1(0.1)$ & 309597 (45.5) & $303.9(41.1)$ & $309699(41.3)$ & $304.0(36.7)$ \\
\hline & Little tunny & Euthynnus alleteratus & 48719 (69.7) & $70.0(78.6)$ & $158014(23.2)$ & $227.0(30.7)$ & $206733(27.5)$ & $297.0(35.9)$ \\
\hline & Bullet tuna & Auxis rochei & $13266(19.0)$ & $12.4(13.9)$ & $116238(17.1)$ & $108.3(14.6)$ & $129504(17.2)$ & $120.6(14.6)$ \\
\hline & Yellowfin tuna & Thunnus albacares & $0(0.0)$ & $0.0(0.0)$ & $26065(3.8)$ & $30.2(4.1)$ & $26065(3.5)$ & $30.2(3.7)$ \\
\hline & Frigate tuna & Auxis thazard & 7859 (11.2) & $6.6(7.4)$ & $42336(6.2)$ & $35.3(4.8)$ & $50195(6.7)$ & $41.8(5.1)$ \\
\hline & Bigeye & Thunnus obesus & $0(0.0)$ & $0.0(0.0)$ & $10300(1.5)$ & $16.0(2.2)$ & $10300(1.4)$ & $16.0(1.9)$ \\
\hline & & Auxis sp. & $0(0.0)$ & $0.0(0.0)$ & $18263(2.7)$ & $18.4(2.5)$ & $18263(2.4)$ & $18.4(2.2)$ \\
\hline & & Total tuna & $69946(100)$ & $89.0(100)$ & $680813(100)$ & $739.1(100)$ & $750759(100)$ & $828.1(100)$ \\
\hline \multirow[t]{8}{*}{ Billfish } & Atlantic sailfish & Istiophorus albicans & $408(95.1)$ & $10.4(82.0)$ & $48(31.6)$ & $1.1(7.9)$ & $456(78.5)$ & $11.5(43.1)$ \\
\hline & Atlantic blue marlin & Makaira nigricans & $5(1.2)$ & $0.7(5.5)$ & $69(45.3)$ & $9.3(66.8)$ & 74 (12.7) & $10.0(37.7)$ \\
\hline & Marlins, sailfishes & Istiophoridae & $14(3.3)$ & $1.4(10.9)$ & $19(12.5)$ & $1.9(13.8)$ & $33(5.7)$ & $3.3(12.4)$ \\
\hline & Swordfish & Xiphias gladius & $0(0.0)$ & $0.0(0.0)$ & $7(4.6)$ & $0.7(5.0)$ & $7(1.2)$ & $0.7(2.6)$ \\
\hline & Atlantic white marlin & Tetrapterus albidus & $2(0.5)$ & $0.2(1.6)$ & $4(2.6)$ & $0.4(2.9)$ & $6(1.0)$ & $0.6(2.3)$ \\
\hline & Black marlin & Makaira indica & $0(0.0)$ & $0.0(0.0)$ & $3(2.0)$ & $0.3(2.2)$ & $3(0.5)$ & $0.3(1.1)$ \\
\hline & Shortbill spearfish & Tetrapturus angustirostris & $0(0.0)$ & $0.0(0.0)$ & $2(1.3)$ & $0.2(1.4)$ & $2(0.3)$ & $0.2(0.8)$ \\
\hline & & Total billfish & $429(100)$ & $12.6(100)$ & $152(100)$ & $13.9(100)$ & $581(100)$ & $26.6(100)$ \\
\hline \multirow[t]{9}{*}{ Other Bony Fish } & Triggerfish & Triggerfish & $343(44.1)$ & $0.2(10.5)$ & $28430(59.6)$ & $19.8(31.4)$ & $28772(59.3)$ & $20.0(30.7)$ \\
\hline & Rainbow runner & Elagatis bipinnulata & $330(42.5)$ & $0.6(31.0)$ & $8705(18.2)$ & $19.7(31.3)$ & 9035 (18.6) & $20.4(31.3)$ \\
\hline & Wahoo & Acanthocybium solandri & $4(0.5)$ & $0.0(1.1)$ & $2992(6.3)$ & $10.7(17.0)$ & $2996(6.2)$ & $10.7(16.5)$ \\
\hline & Carangids & Carangidae & $38(4.9)$ & $0.1(2.8)$ & $2945(6.2)$ & $1.5(2.4)$ & $2983(6.1)$ & $1.6(2.4)$ \\
\hline & Oilfish & Ruvettus pretiosus & $0(0.0)$ & $0.0(0.0)$ & $2111(4.4)$ & $1.1(1.7)$ & $2111(4.4)$ & $1.1(1.6)$ \\
\hline & Dolphinfish & Coryphaenidae & $15(1.9)$ & $0.1(3.5)$ & $1327(2.8)$ & $5.2(8.2)$ & $1342(2.8)$ & $5.2(8.0)$ \\
\hline & Barracudas & Sphyraenidae & $6(0.8)$ & $0.0(0.3)$ & $738(1.5)$ & $3.5(5.6)$ & $744(1.5)$ & $3.5(5.4)$ \\
\hline & & Others & $41(5.3)$ & $1.0(50.7)$ & $489(1.0)$ & $1.6(2.5)$ & $530(1.1)$ & $2.6(4.0)$ \\
\hline & & Total other bony fish & $777(100)$ & $2.0(100)$ & $47737(100)$ & $63.0(100)$ & $48514(100)$ & $65.1(100)$ \\
\hline \multirow[t]{9}{*}{ Sharks(*) } & Silky shark & Carcharhinus falciformis & $1(5.5)$ & $0.0(0.0)$ & $243(75.2)$ & $5.1(58.5)$ & $244(71.5)$ & $5.1(53.4)$ \\
\hline & Unidentified sharks & & $2(11.1)$ & $0.2(23.7)$ & $58(18.0)$ & $2.9(33.0)$ & $60(17.6)$ & $3.1(32.1)$ \\
\hline & Smooth hammerhead & Sphyrna zygaena & $7(39.1)$ & $0.3(37.3)$ & $5(1.5)$ & $0.2(2.7)$ & $12(3.5)$ & $0.6(5.7)$ \\
\hline & Scalloped hammerhead & Sphyrna lewini & $5(27.7)$ & $0.2(23.2)$ & $6(1.9)$ & $0.3(3.2)$ & $11(3.2)$ & $0.5(5.0)$ \\
\hline & Oceanic whitetip shark & Carcharhinus longimanus & $2(11.1)$ & $0.1(8.3)$ & $9(2.8)$ & $0.1(1.6)$ & $11(3.2)$ & $0.2(2.2)$ \\
\hline & Shortfin mako & Isurus oxyrinchus & $1(5.5)$ & $0.1(7.5)$ & $0(0.0)$ & $0.0(0.0)$ & $1(0.3)$ & $0.1(0.7)$ \\
\hline & Dogfish sharks & Squaliforms & $0(0.0)$ & $0.0(0.0)$ & $1(0.3)$ & $0.1(0.6)$ & $1(0.3)$ & $0.1(0.5)$ \\
\hline & Hammerhead shark & Sphyrnidae & $0(0.0)$ & $0.0(0.0)$ & $1(0.3)$ & $0.0(0.5)$ & $1(0.3)$ & $0.0(0.5)$ \\
\hline & & Total sharks & $18(100)$ & $0.8(100)$ & $323(100)$ & $8.8(100)$ & $341(100)$ & $9.6(100)$ \\
\hline \multirow[t]{8}{*}{ Rays } & Chilean devil ray & Mobula coilloti & $26(51.3)$ & $3.9(63.7)$ & $0(0.0)$ & $0.0(0.0)$ & $26(42.2)$ & $3.9(50.1)$ \\
\hline & Giant manta & Manta birostris & $4(7.9)$ & $0.8(13.1)$ & $7(63.6)$ & $1.4(84.4)$ & $11(17.8)$ & $2.2(28.3)$ \\
\hline & Devil fish & Mobula mobular & $6(11.8)$ & $1.0(15.5)$ & $1(9.1)$ & $0.2(9.0)$ & $7(11.4)$ & $1.1(14.1)$ \\
\hline & Spine tail mobula & Mobula rancurelli & $3(5.9)$ & $0.4(7.0)$ & $0(0.0)$ & $0.0(0.0)$ & $3(4.9)$ & $0.4(5.5)$ \\
\hline & Unidentified rays & & $0(0.0)$ & $0.0(0.0)$ & $3(27.3)$ & $0.1(6.5)$ & $3(4.9)$ & $0.1(1.4)$ \\
\hline & Pelagic stingray & Pteroplatytrygon violacea & $11(21.1)$ & $0.0(0.5)$ & $0(0.0)$ & $0.0(0.0)$ & $11(17.3)$ & $0.0(0.4)$ \\
\hline & Cownose rays & Rhinopteridae & $1(2.0)$ & $0.0(0.2)$ & $0(0.0)$ & $0.0(0.0)$ & $1(1.6)$ & $0.0(0.1)$ \\
\hline & & Total rays & $51(100)$ & $6.1(100)$ & $11(100)$ & $1.7(100)$ & $62(100)$ & $7.8(100)$ \\
\hline
\end{tabular}




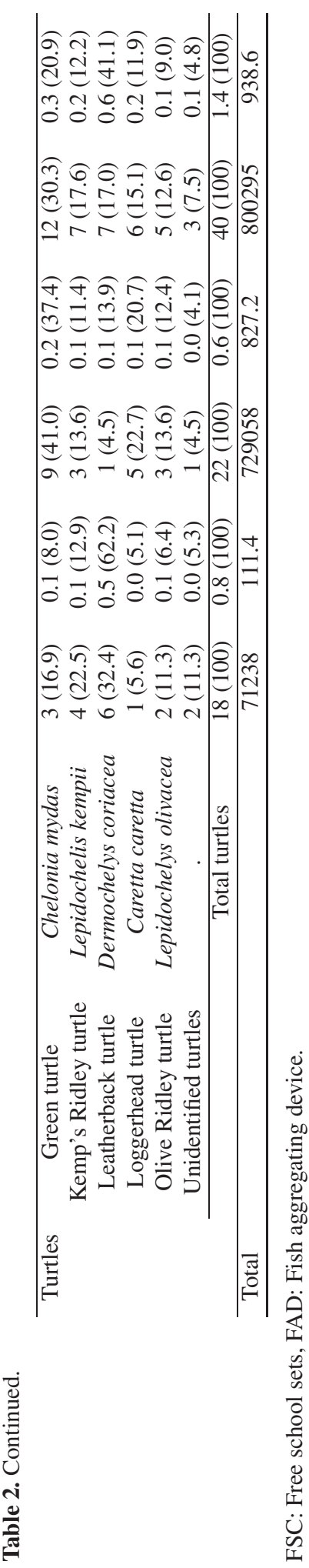

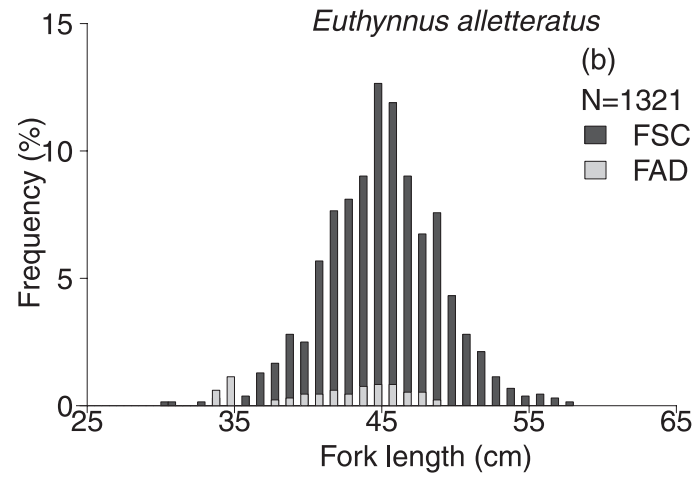

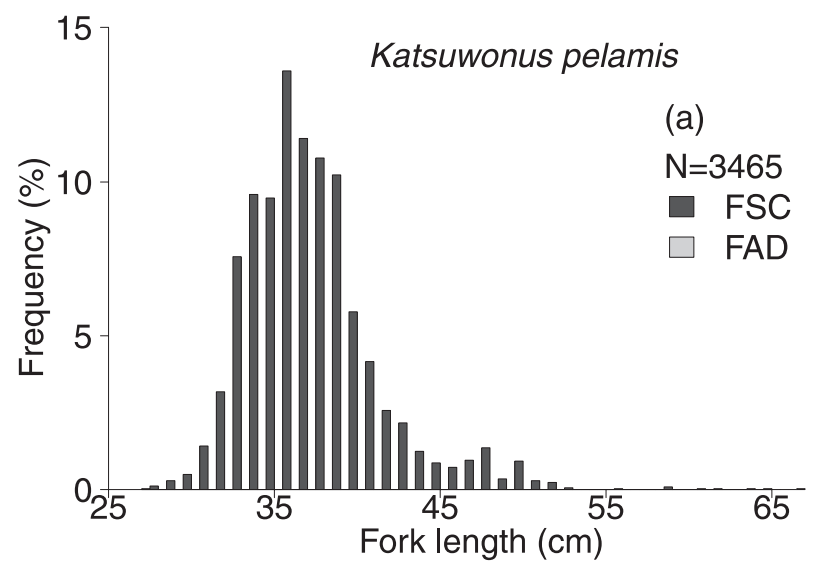

Fig. 1. Length frequency distribution on FAD-associated and free school sets for discarded skipjack, Katsuwonus pelamis (a) and little tunny, Euthynnus alletteratus (b).

to $283 \mathrm{~cm}$ (median $=180 \mathrm{~cm}, 2.5 \%$ and $97.5 \%$ quantiles are $153 \mathrm{~cm}$ and $216 \mathrm{~cm}$, respectively). The length of Atlantic sailfish statistically differed between FAD and free school sets (Student'st-test, $p$-value $<0.05$ ).

\subsection{Other bony fish}

Observers recorded a total of 48514 fish (65 t) as bycatch between 2003 and 2007 (Table 2). Observers on board identified 30 taxonomic categories, but a few species and taxonomic groups dominated the bycatch in numbers or in weight. In both cases, the following seven categories represent around $99 \%$ of the total bony fish bycatch: triggerfish (Balistes punctatus, B. carolinensis, Balistidae, Canthidermis maculatus, Aluterus monoceros), rainbow runner (Elagatis bipinnulata), wahoo (Acanthocybium solandri), carangids (Uraspis secunda, Caranx crysos, Naucrates ductor, Seriola rivoliana, Carangidae), oilfish (Ruvettus pretiosus), dolphinfish (Coryphaena hippurus, C. equiselis, Coryphaenidae), and barracuda (Sphyraena barracuda, Sphyraenidae). More than $97 \%$ of fish, in weight, were caught under FAD-associated sets.

\subsection{Sharks}

Seventeen whale shark (Rhyncodon typus) catch events were reported by observers. These individuals were captured 


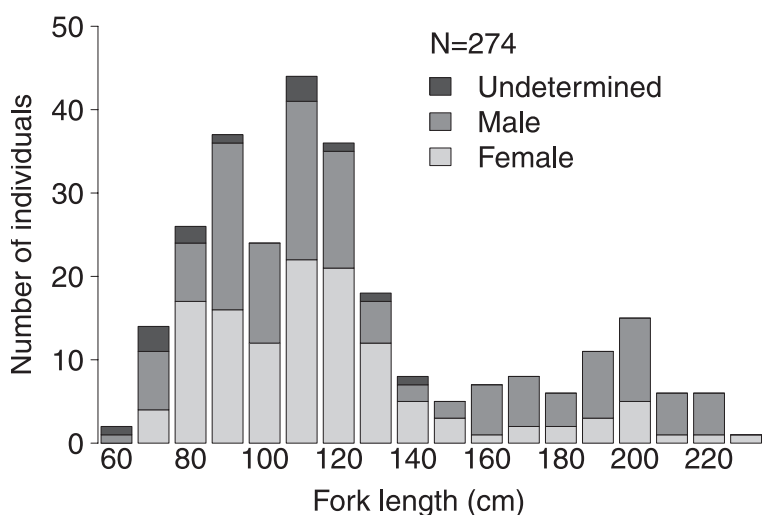

Fig. 2. Length frequency distribution of silky shark Carcharhinus falciformis by sex.

from the second to the fourth quarter of the year, particularly in the Cape Lopez and northeastern equatorial zones (Fig. 4). Whale sharks were discarded alive, and were discarded almost always before the retrieval of the net. Subsequent shark group bycatch estimation did not include whale sharks.

A total of 341 sharks, i.e. $10 \mathrm{t}$, were recorded by observers over the period considered (Table 2). The main species encountered was silky shark (Carcharhinus falciformis), which represented $53 \%$ and $72 \%$ of the shark bycatch in weight and numbers, respectively. Silky sharks were caught with total lengths between 67 and $256 \mathrm{~cm}$, with two modes respectively around 110 and $200 \mathrm{~cm}$ (Fig. 2). No clear pattern in sex ratio was detected for lengths under $160 \mathrm{~cm}$, but $70 \%$ of sharks in the bycatch above $160 \mathrm{~cm}$ were male. Sphyraena zygaena and $S$. lewini also occurred in purse seine catches, representing $11 \%$ and $7 \%$ of the shark bycatch in weight and numbers, respectively (Table 2). Other species, such as Carcharhinus longimanus and Isurus oxyrinchus, were occasionally taken as bycatch. More than $91 \%$ of sharks were caught under FADassociated sets.

\subsection{Rays}

A total of 62 rays ( $8 \mathrm{t}$ ) were recorded by observers over the time period of analysis (Table 2). The main species encountered were the Chilean devil ray (Mobula coilloti), pelagic stingray (Pteroplatytrygon violacea), giant manta (Manta birostris), devil fish (Mobula mobular), and the spine tail mobula (Mobula rancurelli). Due to large variations in size and weight between species, species composition greatly differed between estimates expressed in number or in weight. Rays were mainly caught under free school sets, except for the giant manta ray, which presented similar numbers under both fishing modes.

\subsection{Turtles}

Observations of turtles were occasional and their numbers were almost equal under FAD-associated (54\%) and free school sets $(46 \%)$. A total of 40 individuals were caught over

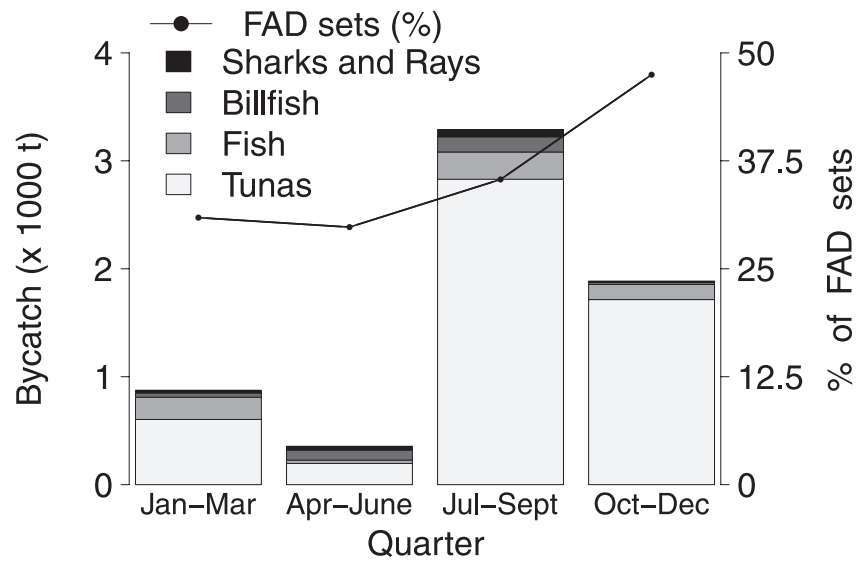

Fig. 3. Total bycatch by quarters and percentage of FAD-associated sets in the entire fishery indicating the higher levels of FAD-fishing during the second half-year.

the 2003-2007 period. Turtle species composition was dominated by the green turtle (Chelonia mydas), followed by the kemp's Ridley turtle (Lepidochelys kempii), the leatherback turtle (Dermochelys coriacea), loggerhead turtle (Caretta caretta), and olive Ridley turtle (Lepidochelys olivacea) (Table 2). Green and loggerhead turtles occurred more frequently under FAD-associated schools than under free school sets, whereas the leatherback turtle appeared more frequently under free school sets. Nearly $98 \%$ of the turtles caught were released alive at sea. Observations of turtles in the catch were mostly reported during the second and third quarters of the year and were geographically scattered across the entire fishing area. Almost all catches of $C$. mydas concerned individuals whose curved carapace length was less than $70 \mathrm{~cm}$. Due to the small number of turtles observed, i.e. 10 individuals per year, no attempt was made to extrapolate the bycatch for this group of species at the fishery level.

\subsection{Marine mammals}

Only two catch events of marine mammals were reported by observers. It occurred during the third quarter period (August and September) and involved free school sets. One event involved a fin whale, Balaenoptera physalus, and the second event involved two humpback whales, Megaptera novaeangliae. All individuals were released alive without being brought on board the vessel. The rarity of these observations impeded any attempt to extrapolate bycatch figures for marine mammals at the fishery level.

\subsection{European bycatch estimation based on large groups of species}

According to the method based on a stratified bycatch ratio for tuna production and a mean annual production of $79300 \mathrm{t}$ for the 2003-2007 period, the French and Spanish tuna purse seine fishery annual bycatch was estimated at about $6400 \mathrm{t}$; this corresponds to $80.8 \mathrm{t} / 1000 \mathrm{t}$ of landed tuna and $7.5 \%$ of the total catch (Table 3). Tunas represented $83 \%$ of the total bycatch, 
Table 3. Estimated bycatch by species group.

\begin{tabular}{ccccccc}
\hline & \multicolumn{2}{c}{ FSC } & \multicolumn{2}{c}{ FAD } & \multicolumn{2}{c}{ Total } \\
\hline & $t$ & $t / 1000 \mathrm{t}$ & $t$ & $t / 1000 \mathrm{t}$ & $t$ & $t / 1000 \mathrm{t}$ \\
\hline Total catch & 46506 & \multicolumn{3}{c}{3919} & & 85704 \\
\hline Production & 45222 & \multicolumn{3}{c}{34076} & 79299 & \\
\hline Bycatch total & 1284 & 28.4 & 5121 & 150.3 & 6405 & 80.8 \\
\cline { 2 - 7 } Tunas & 941 & 20.8 & 4384 & 128.7 & 5326 & 67.2 \\
Bony Fish & 35 & 0.8 & 580 & 17.0 & 616 & 7.8 \\
Billfish & 233 & 5.1 & 88 & 2.6 & 320 & 4.0 \\
Sharks & 13 & 0.3 & 61 & 1.8 & 74 & 0.9 \\
Rays & 62 & 1.4 & 8 & 0.2 & 70 & 0.9 \\
\hline
\end{tabular}

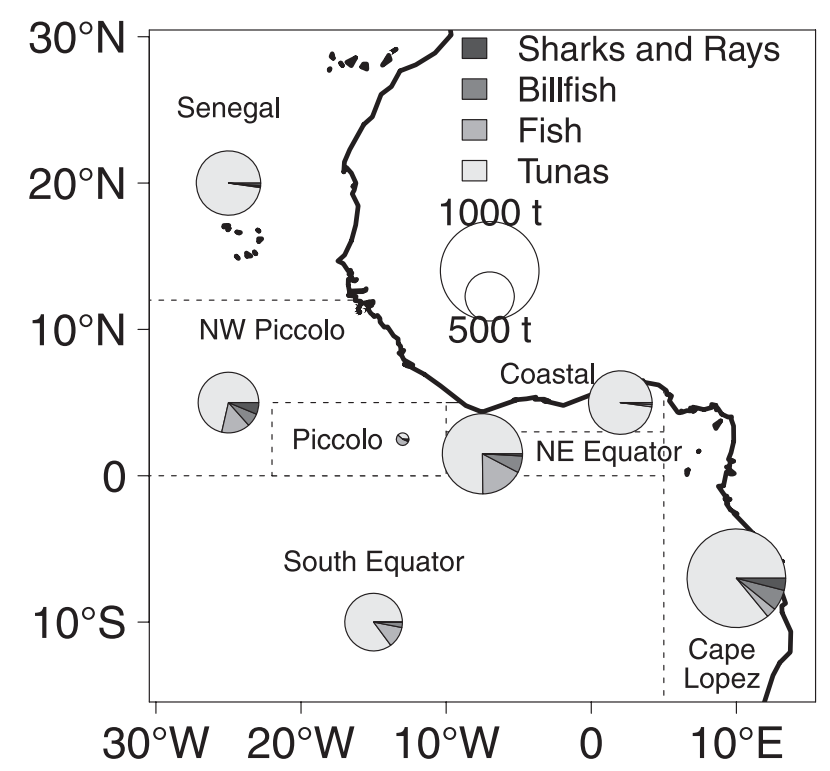

Fig. 4. Spatial variability of bycatch (weight is indicated by size of circles) by species group, and ET area.

corresponding to $67.2 \mathrm{t} / 1000 \mathrm{t}$ of unloaded tuna. The remaining $17 \%$ of the bycatch $(13.6 \mathrm{t} / 1000 \mathrm{t})$ consisted of $10 \%$ bony fish $(7.8 \mathrm{t} / 1000 \mathrm{t}), 5 \%$ billfish $(4.0 \mathrm{t} / 1000 \mathrm{t})$, and 2\% sharks and rays $(1.8 \mathrm{t} / 1000 \mathrm{t})$. The bycatch was higher under FADassociated sets than under free school sets, especially for tunas and other bony fish. Bycatch amounts were lower during the first two quarters of the year and increased sharply during the second half of the year, mostly due to tuna species (Fig. 3). This pattern may be explained by the fact that the fishery targets free schools during the first part of the year, whereas fisheries mostly target FAD sets during the second part of the year. The spatial distribution of the bycatch in terms of the group of species indicated that the major areas were, by order of importance, Cape Lopez, North-East Equator, Coast, North-West Piccolo, Senegal, South East Equator and Piccolo (Fig. 4).

Confidence intervals of bycatch estimates by species group and fishing mode indicated that there was significant variation for the tuna category and during FAD-associated fishing (Fig. 5). This reflects the fact that our dataset was highly influenced by few observations on sets displaying a large tuna bycatch, whereas most of the observations involved sets with almost no tuna bycatch.

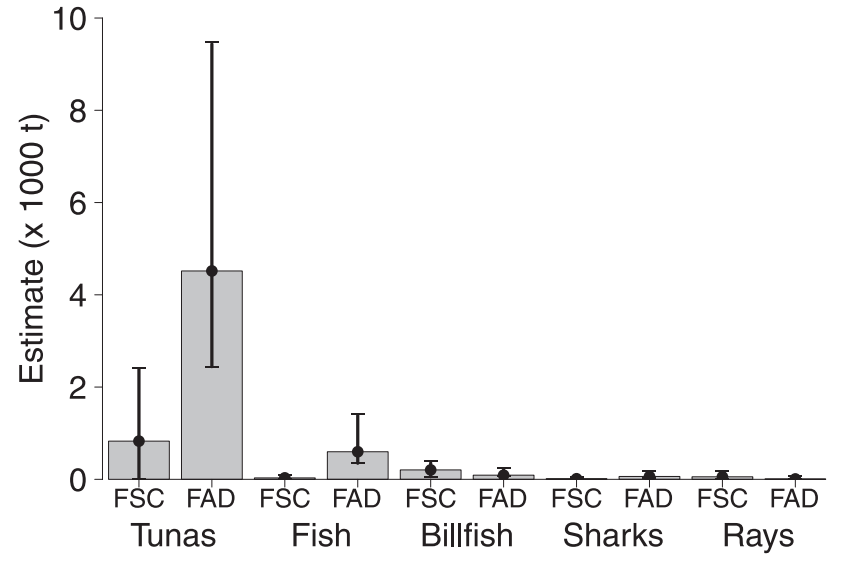

Fig. 5. Estimated bycatch by species group and fishing mode(FAD and FSC). Vertical lines indicate $95 \%$ confidence intervals.

Table 4. Bycatch fate (by-products or discards) estimated by species group.

\begin{tabular}{lccccc}
\hline & \multicolumn{2}{c}{ By-products } & \multicolumn{2}{c}{ Discards } & Total \\
\hline & $\%$ & $t$ & $\%$ & $t$ & $t$ \\
\hline Tunas & 9 & 455 & 91 & 4871 & 5326 \\
Bony Fish & 48 & 294 & 52 & 321 & 616 \\
Billfish & 67 & 215 & 33 & 106 & 320 \\
Sharks & 63 & 46 & 37 & 27 & 74 \\
Rays & 6 & 4 & 94 & 66 & 70 \\
Total & & 1014 & & 5391 & 6405 \\
\hline
\end{tabular}

Extrapolated values of the bycatch fate showed that $84 \%$ of the $6400 \mathrm{t}$ of bycatch is discarded at sea, with the rest being kept for consumption on board or for sale on the local African market (Table 4). According to observers, the tuna bycatch was mostly discarded at sea and was rarely kept on board. Overall, a similar proportion of bony fish was discarded at sea or kept on board as by-products. However, some species are preferred and, while triggerfish and oilfish were discarded in large proportions, rainbow runners, wahoos, carangids, and barracudas were generally kept in wells to be marketed at port or consumed on board. Most billfish caught (67\% in terms of weight) were kept on board as by-products and $33 \%$ were discarded at sea. Sharks were mostly transported to port as whole carcasses, whereas rays were seldom kept on board as by-products. 


\section{Discussion}

Our results showed that the European tuna purse seine fishery of the eastern Atlantic Ocean generates lower levels of bycatch than other fisheries, consistent with global assessments of discard and bycatch (Alverson et al. 1994; Chuenpagdee et al. 2003; Kelleher 2005). The overall ratio of bycatch to total catch $(7.5 \%)$ estimated in this study indicated that the tuna purse seine fishery has an almost ten-fold lower ratio than shrimp fisheries and a six-fold lower ratio than tuna longline fisheries (Kelleher 2005). Our results also confirmed previous observations indicating that the fishing mode substantially affects the species composition and magnitude of the bycatch: FAD-associated fishing by tuna purse seine fisheries leads to greater amounts of bycatch and discard than free school fishing (Ariz et al. 1999; Hallier and Parajua 1999; Fonteneau et al. 2000). Quantitative estimates may be compared with previous studies on purse seine fisheries in both the Indian and Atlantic Oceans. In the Atlantic Ocean, Delgado de Molina et al. (2000) reported bycatch estimates for the same fishery between 1997 and 1999: these appeared to be significantly lower than those found in our study, especially for FAD sets. By contrast, our results for both fishing modes were similar to the estimates for the 1997-2002 ICCAT tuna moratorium periods when FAD fishing was prohibited during November, December, and January in a wide area of the Gulf of Guinea (Goujon 2004). Finally, Sarralde et al. (2004) reported overall levels of tuna discards and bycatch during the 2002-2003 Spanish ICCAT tuna moratorium that were similar to those presented here for both fishing modes. Further analysis is needed to explain the differences in findings presented by Delgado de Molina et al. (2000). However, it should be noted that the bigeye observer programme was not specifically oriented towards bycatch observations and this component of the catch may have been underestimated. In the Indian Ocean, when tunas are not taken into account, our results were very similar to bycatch levels estimated for the European purse seine tuna fishery (Amandè et al. 2008). Romanov (2008) indicates that tunas were never discarded, but were retained for sale by the Soviet purse seine fishery. While the proportion of bycatch under free school sets in the Soviet fishery was similar to those obtained in our study, it was two times higher than our estimates for FAD sets.

A major finding of our analysis is that tunas, mostly skipjack and little tunny, constitute the great majority (83\%) of the bycatch in the European tuna purse seine fishery of the eastern Atlantic Ocean; this bycatch is discarded in $91 \%$ of instances (Fig. 5 and Table 4), but this bycatch estimate appeared to be significantly influenced by there being few sets with large amounts of small tuna that were discarded. The amounts of discard coincided with results for the French fleet derived from the observer programme conducted from 1997-2002 through the time-area closure implemented in the Gulf of Guinea (Goujon 2004). However, it was higher than the amounts observed during the 2002-2003 period for the Spanish fleet (Sarralde et al. 2004).

The tuna bycatch rate, estimated at $67.2 \mathrm{t} / 1000 \mathrm{t}$ of tuna produced by the European tuna purse seine fishery in the eastern Atlantic Ocean is higher than that estimated for the same fishery operating in the Indian Ocean, where overall tuna discard estimates were of $19.2 \mathrm{t} / 1000 \mathrm{t}$ of tuna produced, repre- senting only $54 \%$ of the total bycatch (Amandè et al. 2008). This result is counter intuitive, as the Atlantic Ocean tropical tuna fishery benefits from market facilities for damaged or undersize major tunas, small tunas, and various fish species in Côte d'Ivoire (Bard and Amon-Kothias 1985; Amon-Kothias et al. 1996; Romagny et al. 2000). It was then expected that tuna for non-commercial purposes would be kept on board in larger proportions than those fished in the Indian Ocean, as they could be sold on the Abidjan market as "Faux poisson", similar to that observed for bony fish, billfish, and sharks. A possible explanation for this difference in tuna discarding rates between the Atlantic and Indian Ocean fisheries may be linked to differences in abundance, productivity and catchability of small tunas. For instance, the mean weight of skipjack tuna in the Atlantic Ocean catch is significantly lower $(2.1 \mathrm{~kg})$ than in the Indian Ocean fishery (2.9 kg) (Pianet et al. 2008).

Billfish appear to be the third major component of bycatch after tunas and bony fish in the Atlantic Ocean. This is in contrast to previous studies (Stretta et al. 1997; Delgado et al. 2000; Goujon 2004), which ranked sharks as the third most abundant component of the bycatch. In the Indian Ocean, sharks are also the third most abundant species in the bycatch (Romanov 2002; Amandè et al. 2008). Gaertner et al. (2002) estimated an average annual bycatch of $245.1 \mathrm{t}$ of marlin and $42.4 \mathrm{t}$ of sailfish corresponding to $1.8 \mathrm{t} / 1000 \mathrm{t}$ and $0.3 \mathrm{t} / 1000 \mathrm{t}$, respectively, on the basis of 1884 observed sets from June 1997 to May 1999 during the European Union Bigeye Programme. Our results for billfish $(4 \mathrm{t} / 1000 \mathrm{t})$ are slightly higher than these estimates, suggesting that a switch in abundance between skarks and billfish may have occurred during that period.

Turtles are rarely caught during purse seine operations and, if it does happen, they are discarded alive. Green turtle (C. mydas), the main species caught, is a coastal species. However, juveniles, with an average size of 30-50 cm, are frequently found in the pelagic habitat in their early years of life before reaching coastal habitat. During this period, turtles are vulnerable to high sea fishery operations and seek artificial or natural drifting devices to rest. Adults of this species are not reported, likely due to the fact that adults in the open sea phase are in nesting or post nesting migrations and do not use FAD surfaces for stopping and resting (J. Bourjea comm. pers.). Our observations only concern turtles that were effectively caught during set operations and that were brought on board like any other bycatch species. These observations and the related derived quantitative estimates do not take into account the hidden and non estimated number of turtles that die due to entangling while resting on FADs, which may be the major source of mortality. Eliminating the use of net materials in FAD construction could be a simple technological solution for solving this problem.

By-product quantities estimated by observers and extrapolated to the fishery level may be compared to "Faux poisson" landings, which are systematically counted. A preliminary comparison for the same period indicated that there is a significant underestimation of tuna by-products in observer data: the "Faux poisson" monitoring system provided an estimate of $4300 \mathrm{t}$, whereas extrapolated observer data results in an estimate of only $455 \mathrm{t}$ (Table 4 and Fig. 6). This difference may be explained by the fact that significant quantities 


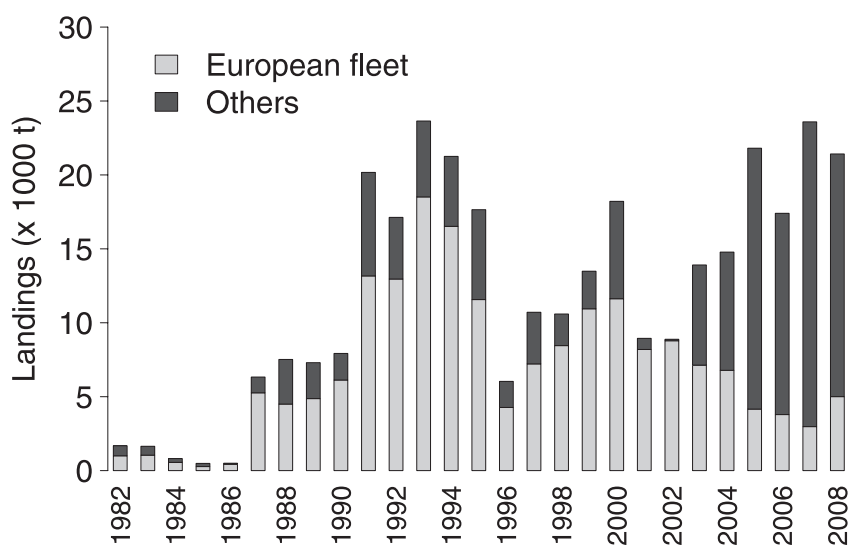

Fig. 6. Evolution of fish landings as by-products, called "Faux poisson" on Abidjan local market in Côte d'Ivoire.

of major tuna species (mainly skipjack), initially kept in wells just after capture and categorized as production by observers, are finally sorted before landing in Abidjan and downgraded to "Faux poisson" because they are minor tunas, too small, or too damaged for canneries. Thus, the estimates for the tuna bycatch by-poduct component may still have been underestimated in this study. A better understanding and estimation of sorting practices associated with tuna production during landings is required to improve our estimates of the total bycatch.

We used the "fishing set" as a statistical unit instead of a "fishing trip", based on the low number of observed trips in our data set. However, the number of fishing sets was lower than five sets in some stratified data sets. Consequently, the total bycatch estimate, based on the ratio estimator method, may be biased. However, we were interested in analyzing the magnitude of the bycatch caught by the French and Spanish purse-seine fishery and not the optimum method for analysing bycatch, or the factors affecting their variability. So, no attempt was made to estimate the minimum variance in this study.

The ratio estimator method was based on the strong assumption of a linear relationship between bycatch and fish production. This assumes that the bycatch is null when tuna production is null, whereas observations indicate that this is an approximation, especially for some groups of species, such as billfish.

However, this method has been widely used in fishery science (Stratoudakis 1999; Ye et al. 2000; Gaertner et al. 2002; Borges et al. 2005; Amandè et al. 2008) because of its practical aspects, but it can lead to biases and uncertainties due to the nature of bycatch data and its relationship with the auxiliary variable (Rochet and Trenkel 2005). Indeed, the true stochastic processes that generate the data are generally unknown and specific modeling approaches based on mixture distributions (Perkins and Edwards 1996; Fletcher et al. 2005; Minami et al. 2007) should be used at the species level or trophic group level. These approaches complemented with the raising factor method could be used to better identify the factors affecting bycatch and eventually improve our estimates for the European purse seine fishery in the eastern Atlantic Ocean.

Furthermore, we used a spatial and temporal stratification to improve our estimates of total bycatch. It is worth pointing out that areas used are sampling strata considered for the multispecies sampling scheme to correct for errors in the composition of tuna species that were reported caught in logbooks (Pallarés and Hallier 1997). This sampling scheme has been derived from a statistical analysis of historical tuna catches and may therefore not be appropriate to estimate the bycatch for other species. In addition, simplifying the fishing mode variable to only two categories (FAD and FSC) may not be accurate for bycatch assessment, as evidence has shown that some large pelagic species, e.g. Sphyrnidae, can be concentrated on seamounts (Klimley et al. 1988).

\section{Conclusion}

Observer programmes conducted by Spain and France within the European Data Collection Regulation framework provided detailed and rich information on bycatch and discards. Coordination between programmes, as is currently occurring between French and Spanish scientific teams, allows the use of larger datasets, through the gathering data, thus providing acceptable observation levels, e.g. better spatial and temporal distribution of fishing sets. Tuna purse seining generates relatively low levels of bycatch. Although, as some biologically sensitive species groups such as sharks and turtles are impacted, a cautious analysis at the species level should be conducted to precisely assess the relative impact of this fishery on these groups. Furthermore, analyses comparing ongoing comparative bycatch analysis between the Indian and Atlantic Oceans along with observations made during previous periods will certainly provide useful insights for a better understanding of the factors involved in bycatch and discarding practices of the European tuna purse seine fishery and also for assessing the effects of this fishery on the ecosystem compared with other fishing systems.

Acknowledgements. The authors are grateful to the observers involved in data collection. They thank the fishing masters and their fishing companies for their close collaboration with the observers and IRD/IEO/AZTI scientists. These observer programmes are financed through the European Data Collection Regulation, EC-DCR $\mathrm{N}^{\circ} 1543 / 2000,1639 / 2001$ and 1581/2004. We also thank A. Fonteneau (IRD), J. Bourjea (Ifremer) for helpful comments and suggestions, and P. Cauquil (IRD) and A. Damiano (IRD) for database development and management. Finally, the authors thank the anonymous referees who greatly helped in improving the presentation of our findings.

\section{References}

Alverson D.L., Freeberg M.H., Pope J.G., Murawski S.A., 1994, A global assessment of fisheries by catch and discards. FAO Fish. Tech. Pap. 339, 233 p.

Amandè M.J., Ariz J., Chassot E., Chavance P., Delgado de Molina A., Gaertner D., Murua H., Pianet R., Ruiz J., 2008, By-catch and discards of the European purse seine tuna fishery in the Indian ocean: Characteristics and estimation for the 2003-2007 period. IOTC-2008-WPEB-12, 23 p. 
Amon-Kothias J.B., Bard F.X., Hervé A., 1996, Mise à jour des quantités de "Faux poissons" débarqués par les senneurs à Abidjan. Coll. Vol. Sci. Pap. ICCAT 45, 227-228.

Ariz J., Delgado de Molina A., Fonteneau A., Gonzalez Costas F., Pallarés P., 1999, Logs and tunas in the eastern tropical Atlantic. A review of present knowledge and uncertainties. In: Scott M.D., Bayliff W.H., Lennert-Cody C.E., Schaefer K.M. (Eds.). Proc. International Workshop on the Ecology and Fisheries for Tunas Associated with Floating Objects, February 11-13, 1992, InterAm. Trop. Tuna Comm. Spec. Rep. 11, 21-65.

Bard F.X., Amon-Kothias J.B., 1985, Evaluation des débarquements de thonidés mineurs et istiophoridés au port d'Abidjan de 19811984. Coll. Vol. Sci. Pap. ICCAT 23, 333-336.

Borges L., Zuur A.R., Rogan E., Officer R., 2005, Choosing the best sampling unit and auxiliary variable for discards estimations. Fish. Res. 75, 29-39.

Canty A., Ripley B., 2010, Boot: Bootstrap R (S-Plus) Functions. R package version 1.2-42.

Chuenpagdee R., Morgan L.E., Maxwell S.M., Norse E.A., Pauly D., 2003, Shifting gears: assessing collateral impacts of fishing methods in U.S. waters. Front. Ecol. Environ. 1, 517-524.

Davies R.W.D., Cripps S.J., Nickson A., Porter, G., 2009, Defining and estimating global marine fisheries bycatch. Mar. Pollut. 33, 661-672.

Delgado de Molina A., Ariz J., Gaertner D., Santana J.C., 2000, Estimación de la importancia de las capturas de especies accesorias y de descartes en la pesquería de cerco de túnidos tropicales en el océano Atlántico oriental. Collect. Vol. Sci. Pap. ICCAT 51, 1859-1875.

FAO, 1999, Guidelines for the routine collection of capture fishery data. Prepared at the FAO/DANIDA Expert Consultation. Bangkok, Thailand, 18-30 May 1998. FAO Fisheries Tech. Pap. 382, Rome, $113 \mathrm{p}$.

Fletcher D., MacKenzie D., Villouta E., 2005, Modelling skewed data with many zeros: a simple approach combining ordinary and logistic regression. Environ. Ecol. Stat. 12, 45-54.

Fonteneau A., Pallarés P., Pianet R., 2000, A worldwide review of purse seine fisheries on FADs. In: Cayré P., Le Gall J. Y., Taquet M. (Eds.) Pêche thonière et dispositifs de concentration de poissons, Colloque Caraïbe-Martinique, Trois-Ilets, 15-19 octobre 1999. Institut de recherche pour le développement, Institut français de recherche pour l'exploitation de la mer, Ecole nationale supérieure agronomique de Rennes. Editions Quae, 684 p.

Gaertner D., Ménard F., Develter C., Ariz J., Delgado de Molina A., 2002, By-catch of billfishes by the European tuna purse seine fishery in the Atlantic Ocean. Fish. Bull. 100, 683-689.

Garcia S., Zerbi A., Do Chi T., Lasserre G., 2003, The ecosystem approach to fisheries. Issues, terminology, principles, institutional foundations, implementation and outlook. FAO Fish. Tech. Pap. 443, Rome, 76 p.

Goujon M., 2004, Informations sur les captures accessoires des thoniers senneurs gérés par les armements français d'après les observations faites par les observateurs embarqués pendant les plans de protection des thonidés de l'Atlantique de 1997 à 2002. Coll. Vol. Sci. Pap. ICCAT 56, 414-431.

Hall M.A., García M., Lennert-Cody C.E., Arenas P., Miller F., 1999, The association of tunas with floating objects and dolphins in the eastern Pacific Ocean: a review of the current purse-seine fishery, in: Scott M.D., Bayliff W.H., Lennert-Cody C.E., Schaefer K.M. (Eds.). Proc. International Workshop on the Ecology and
Fisheries for Tunas Associated with Floating Objects, February 11-13, Inter-Am. Trop. Tuna Comm. Spec. Rep. 11, 87-194.

Hall M.A., Alverson D.L., Metuzals K.I., 2000, By-Catch: Problems and Solutions. Mar. Pollut. Bull. 41, 204-219.

Hallier J.P., Parajua J.I., 1999, Review of tuna fisheries on floating objects in the Indian Ocean. In: Scott M.D. Bayliff W.H., LennertCody C.E., Schaefer K.M. (Eds.). Proc. International Workshop on the Ecology and Fisheries for Tunas Associated with Floating Objects, February 11-13, 1992, Inter-Am. Trop. Tuna Comm. Spec. Rep. 11, 195-221.

Kelleher K., 2005, Discards in the world's marine fisheries: an update. FAO Fish. Tech. Pap. 470, Rome, 131 p.

Klimley A.P, Butler S.B., Nelson D.R., Stull A.T., 1988, Diel movements of scallopped hammerhead sharks, Sphyrna lewini Griffith and Smith, to and from a seamount in Gulf of California. J. Fish Biol. 33, 751-761.

Lawson T., 2001, Method for analysing bycatch with observer data. SCTB14 Working Paper. Noumea, New Caledonia: Secretariat of the Pacific Community, 14 p.

Lennert-Cody C.E., 2001, Effects of sample size on bycatch estimation using systematic sampling and spatial post-stratification: summary of preliminary results. IOTC Proc. 4, 48-53.

Maguire J.J., Sissenwine M., Csirke J., Grainger R., Garcia S., 2006, The state of world highly migratory, straddling and other high seas fishery resources and associated species. FAO Fish. Tech. Pap. 495, Rome, 84 p.

Minami M., Lennert-Cody C.E., Gao W., Romàn-Verdesoto M., 2007, Modeling shark bycatch: The zero-inflated negative binomial regression model with smoothing. Fish. Res. 84, 210-221.

Pallarés P., Hallier J.P., 1997, Analyse du schéma d'échantillonnage multi-spécifique des thonidés tropicaux. DG-Pêche n 95/37, 1995-1997.

Pallarés P., Petit C., 1998, Tropical tunas: New sampling and data processing strategy for estimating the composition of catches by species and size. Coll. Vol. Sci. Pap. ICCAT 48, 230-246.

Pascoe S., 1997, By-catch management and the economics of discarding. FAO Fish. Tech. Pap. 370, Rome, 137 p.

Perkins P.C., Edwards E.F., 1996, A mixture model for estimating discarded bycatch from data with many zero observations: tuna discards in the eastern tropical Pacific Ocean. Fish. Bull. 94, 330340.

Pianet R., Pallarés P., Petit C., 2000, New sampling and data processing strategy for estimating the composition of catches by species and sizes in the European purse seine tropical tuna fisheries. IOTC-WPDCS/2000/10.

Pianet R., Delgado de Molina A., Doriso J., Bretaudeau P., Hervé A., Ariz J., 2008, Statistics of the main purse seine fleets fishing in the Indian Ocean (1981-2007). IOTC-2008-WPTT-05, 25 p.

Pianet R., Dewals P., Delgado de Molina A., Ariz J., Sarralde R., Dédo R., Sow F., 2009, Statistiques de la pêcherie thonière européenne et assimilée durant la période 1991-2007. Coll. Vol. Sci. Pap. ICCAT 64, 1133-1158.

Rochet M-J., Trenkel V. M., 2005, Factors for the variability of discards, assumptions and field evidence. Can. J. Fish. Aquat. Sci. 62, 224-235.

Romagny B., Ménard F., Dewals P., Gaertner D., N'Goran N., 2000. Le "faux-poisson" d'Abidjan et la pêche sous DCP dérivants dans l'Atlantique tropical Est : circuit de commercialisation et rôle socio-économique. In : Cayré P., Le Gall J.Y., Taquet M. (Eds.) Pêche thonière et dispositifs de concentration 
de poissons, Colloque Caraïbe-Martinique, Trois-Ilets, 15-19 octobre 1999. Institut de recherche pour le développement, Institut français de recherche pour l'exploitation de la mer, Ecole nationale supérieure agronomique de Rennes. Editions Quae, 28, 634-652.

Romanov E.V., 2002, By-catch in the tuna purse-seine fisheries of the western Indian Ocean. Fish. Bull. 100, 90-105.

Romanov E.V., 2008, Bycatch and discards in the Soviet purse seine tuna fisheries on FAD-associated schools in the north equatorial area of the Western Indian Ocean. West. Indian Ocean J. Mar. Sci. 7, 163-174.

Sánchez S., Murua H., González I., Ruiz J., 2007, Optimum sample number for estimating shark by-catch in the Spanish Purse seiners in the western Indian Ocean. IOTC-2007-WPTT-26, 6 p.

Santana, J.C., Delgado de Molina, A., Delgado de Molina, R., Ariz R., Stretta J.M., Domalain, G., 1998, Lista faunística de las especies asociados a las capturas de atún de las flotas de cerco comunitarias que faenan en las zonas tropicales de los océanos Atlántico e Indico. Coll. Vol. Sci. Pap. ICCAT 48, 129-137.
Sarralde R., Ariz J., Delgado de Molina A., Pallarés P., Santana, J.C., 2004, Análisis de los datos obtenidos por observadores en atuneros cerqueros españoles en el océano Atlántico durante las últimas moratorias sobre objetos flotantes (2001-2002 y 20022003). ICCAT Coll. Vol. Sci. Pap. 56, 401-413.

Stratoudakis Y., Fryer R.J., Cook R.M., Pierce G.J., 1999, Fish discarded from Scottish demersal vessels: estimators of total discards and annual estimates for targeted gadoids. ICES J. Mar. Sci. 56, 592-605.

Stretta J.M., Delgado de Molina A., Ariz J., Domalain G., Santana J. C., 1997, Les espèces associées aux pêches thonières tropicales. Coll. Vol. Sci. Pap. ICCAT 46, 250-254.

Thompson S.K., 2002, Sampling. Wiley, New-York, Wiley Series in Probability and Mathematical Statistics.

Ye Y., Alsaffar A.H., Mohammed H.M.A., 2000, Bycatch and discards of the Kuwait shrimp fishery. Fish. Res. 45, 9-19. 